"This document is the Accepted Manuscript version of a Published Work that appeared in final form in ACS Catalysis, copyright (C) 2017 American Chemical Society after peer review and technical editing by the publisher. To access the final edited and published work see [insert ACS Articles on Request author-directed link to Published Work, see http://pubs.acs.org/doi/pdf/10.1021/acscatal.6b02860

\title{
Backbone Immobilization of the Bis(bipyridyl)pyrazolate Diruthenium Catalyst for Electrochemical Water Oxidation
}

\author{
Jann Odrobina, ${ }^{\dagger, \#}$ Julius Scholz, ${ }^{\ddagger, \#}$ Andrea Pannwitz, ${ }^{\dagger}$ Laia Francàs, ${ }^{\S}$ Sebastian Dechert, ${ }^{\dagger}$ \\ Antoni Llobet, ${ }^{\S, \square *}$ Christian Jooß, ${ }^{\ddagger, \& *}$ and Franc Meyer ${ }^{\dagger, \& *}$ \\ †Institute of Inorganic Chemistry, Georg-August-University, Tammannstraße 4, D-37077 Göttingen, \\ Germany \\ ‡ Institute for Materials Physics, Georg-August-University, Friedrich-Hund-Platz 1, D-37077 Göttingen, \\ Germany \\ $\S$ Institute of Chemical Research of Catalonia (ICIQ), Av. Països Catalans 16, E-43007 Tarragona, Spain \\ - Departament de Química, Universitat Autònoma de Barcelona, 0846o Cerdanyola del Vallès, Barcelo- \\ na, Spain \\ \& International Center for Advanced Studies of Energy Conversion (ICASEC), Georg-August-University, \\ D-37077 Göttingen, Germany
}

\footnotetext{
ABSTRACT: Efficient catalysts for water oxidation are key to all scenarios for artificial solar water splitting, and in case of molecular catalysts their immobilization on conductive solid supports is considered essential for the construction of a photoelectrochemical cell. In this work, derivatives of the rugged 3,5bis(bipyrid
} 